\title{
Spatial Organization of the Micromollusc Community under Recreational Load
}

\section{Nadiia Yorkina ( $\nabla$ nadyayork777@gmail.com )}

Department of Ecology, General Biology and Environmental Management, Bogdan Khmelnitsky Melitopol State Pedagogical University, Hetmanska st., 20, 72318, Melitopol, Ukraine https://orcid.org/0000-0001-9996-195X

\section{Natalia Tarusova}

Departament of Geoecology and Land Management, Dmytro Motorny Tavria State Agrotechnological University, 18 B. Khmelnytsky Ave, 72312, Melitopol, Ukraine

\section{Ava Umerova}

Department of Ecology, General Biology and Environmental Management, Bogdan Khmelnitsky Melitopol State Pedagogical University, Hetmanska st., 20, 72318, Melitopol, Ukraine

\section{Polina Telyuk}

Department of Ecology, General Biology and Environmental Management, Bogdan Khmelnitsky Melitopol State Pedagogical University, Hetmanska st., 20, 72318, Melitopol, Ukraine

\section{Yevheniia Cherniak}

Department of Ecology, General Biology and Environmental Management, Bogdan Khmelnitsky Melitopol State Pedagogical University, Hetmanska st., 20, 72318, Melitopol, Ukraine

\section{Research Article}

Keywords: Urban ecology, Micromolluscs, Soil aggragates, Soil compaction, Urban park

Posted Date: June 1st, 2021

DOl: https://doi.org/10.21203/rs.3.rs-579437/v1

License: (1) (i) This work is licensed under a Creative Commons Attribution 4.0 International License. Read Full License 
ISSN 2581-6853

OPEN 2 ACCESS Freely available online
M - $\mathbf{0 0 2 1 3} \mid$ Research Article

\title{
Spatial Organization of the Micromollusc Community under Recreational Load
}

\author{
Nadiia Yorkina ${ }^{* 1}$, Natalia Tarusova ${ }^{2}$, Ava Umerova ${ }^{3}$, Polina Telyuk ${ }^{4}$, Yevheniia Cherniak ${ }^{5}$ \\ ${ }^{1}$ Department of Ecology, General Biology and Environmental Management, Bogdan Khmelnitsky Melitopol State \\ Pedagogical University, Hetmanska st., 20, 72318, Melitopol, Ukraine. Email: nadyayork777@ gmail.com \\ ${ }^{2}$ Departament of Geoecology and Land Management, Dmytro Motorny Tavria State Agrotechnological University, \\ 18 B. Khmelnytsky Ave, 72312, Melitopol, Ukraine. Email: natalia.tarusova@tsatu.edu.ua \\ ${ }^{3}$ Department of Ecology, General Biology and Environmental Management, Bogdan Khmelnitsky Melitopol State \\ Pedagogical University, Hetmanska st., 20, 72318, Melitopol, Ukraine. Email: avaumerova1994@ gmail.com \\ ${ }^{4}$ Department of Ecology, General Biology and Environmental Management, Bogdan Khmelnitsky Melitopol State \\ Pedagogical University, Hetmanska st., 20, 72318, Melitopol, Ukraine. Email: pollytelyuk@ gmail.com \\ ${ }^{5}$ Department of Ecology, General Biology and Environmental Management, Bogdan Khmelnitsky Melitopol State \\ Pedagogical University, Hetmanska st., 20, 72318, Melitopol, Ukraine. Email: evgenya1551@ gmail.com \\ *Corresponding author |ORCID: 0000-0001-9996-195X
}

\begin{abstract}
How to cite this paper: Yorkina, N., Tarusova, N., Umerova, A., Telyuk, P. and Cherniak, Y. (2021). Spatial Organization of the Micromollusc Community under Recreational Load. Grassroots Journal of Natural Resources, 4(2): 1-22. Doi: https://doi.org/10.33002/nr2581.6853.040201
\end{abstract}

Received: 18 April 2021

Reviewed: 30 April 2021

Provisionally Accepted: 03 May 2021

Revised: 05 May 2021

Finally Accepted: 07 May 2021

Published: 05 June 2021

Copyright (C) 2021 by author(s)

This work is licensed under the Creative Commons Attribution International License (CC BY 4.0). http://creativecommons.org/licenses/by/4.0/
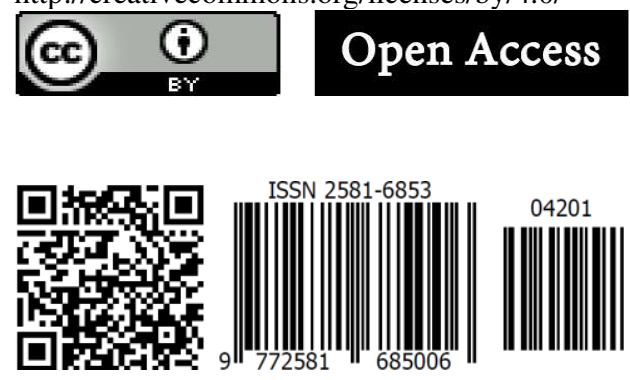

\begin{abstract}
The recreational load is an important factor in transforming the living conditions of living organisms in the urban environment. This article examines the role of recreation as a driver of the changing habitat of soil micromolluscs in the park environment in an urban landscape. The hypothesis that recreational exposure changes the hierarchical organization of the spatial distribution of the micromollusc community was tested. An experimental polygon was located in Novooleksandrivskiy Park (Melitopol, Ukraine) and represented 7 transects with 18 test points in each. The set of soil properties explained $24.7 \%$ of the variation in the mollusc community. The distance from trees was able to explain $6.8 \%$ of mollusc community variation. The distance from recreational pathways was able to explain $12.2 \%$ of the variation in the mollusc community. The spatial eigenfunctions were able to explain $54.2 \%$ of mollusc community variation. The spatial patterns of variation in the structure of the assemblage of molluscs were found to be due to various causes. Thus, the broad-scale component was due to the distance from trees and the distance fro $\mathrm{m}$ the recreational pathways and was associated with the variability of soil penetration resistance, aggregate structure, electrical conductivity, soil moisture and density. The recreational load is the cause of this pattern formation. In turn, the medium-scale component reflected the influence of soil aggregate composition on the mollusc community and components independent of soil properties. The fine-scale component reflected the variability of the mollusc community, which was independent of soil properties.
\end{abstract}

Keywords

Urban ecology; Micromolluscs; Soil aggragates; Soil compaction; Urban park 
Grassroots Journal of Natural Resources, Vol.4, No.2 (June 2021), pp.1-22 | ISSN 2581-6853 | CODEN GJNRA9

Doi: https://doi.org/10.33002/nr2581.6853.040201

OPEN OA ACCESS Freely available online

\section{Introduction}

In the urban environment there is a significant transformation of various components of the landscape, which worsens the modes of existence of biotic components of ecosystems and human living conditions. Urban parks perform a number of the most important ecological services: carbon sequestration, seed dispersal, erosion prevention, water purification, air purification and habitat quality (Kunakh et al., 2020; Mexia et al., 2018). Functional efficiency of forest plantations in urban environment depends on sustainability and diversity of ecosystems formed within them. The urban environment is stressed not only by pollution, but also by heat and drought, creating arid conditions. Trees are passively exposed to the microclimate, but they also actively modify it, and they perform important ecosystem services of the city (Lüttge and Buckeridge, 2020). The destruction of habitat occurs as the intensity of urbanization increases (Yorkina, 2016). The growth of population and the expansion of built-up areas caused by urbanization can have a significant impact on the supply and distribution of critical ecosystem services. A correlation between urbanization and ecosystem services has been established. Urbanization causes a general decline in ecosystem services, where urbanization and ecosystem services showed a negative spatial correlation (Wang et al., 2020). The hotspots that retain biota become increasingly fragmented in urban environments and diminish as the gradient of urbanization increases (Collins et al., 2000). Soil invertebrates in urban environments are taxonomically and functionally diverse. This is contributed to by the specific features of the soil as a habitat. The soil has protective properties, which facilitates the survival of pedobionts even under conditions of significant anthropogenic impact (Byrne et al., 2008; Byrne and Bruns, 2004; Joimel et al., 2017; Rochefort et al., 2006; Schrader and Böning, 2006). Nevertheless, the communities of invertebrates of urban soils are sensitive to the variability of physical and chemical properties of urban soils and land-use practices (Bray et al., 2019).

The soil invertebrates respond to many human activities (Yorkina et al., 2020). Recreation is a factor that significantly transforms the living conditions of soil invertebrates. Recreation affects not only the vegetation cover and soil properties, but also the condition of the complex of soil invertebrates. Recreation contributes to soil compaction, the growth of a network of footpaths and the formation of a special structure of soil cover, consisting of an alternation of dense footpaths and areas outside the footpaths. In the short term, diversity and abundance of soil invertebrate communities will decline due to urbanization. In the long term, the increasing tolerance of an increasing number of species may lead to changes in the structure and size of communities (Salminen et al., 2001). The physical disturbance of the soil, heavy metal contamination, pesticide contamination, the timing and magnitude of human exposure, and the history of land use affect the soil animals (Jones and Leather, 2012; Mcintyre et al., 2000; Pavao-Zuckerman, 2008; PavaoZuckerman and Coleman, 2007; Yorkina et al., 2019). The formed network of footpaths violates the integrity of forest ecosystems, the spatial continuity of grass cover, litter, and soil, leading primarily to changes in populations of soil invertebrates as a result of fragmentation of habitats of living organisms. In recreational forests, soil invertebrates are directly impacted, which is mainly expressed in their mechanical destruction and indirectly transforms their ecological niches (reduction of living space and food reserves). In urban forest parks, with increasing recreational pressure, the number, biomass, and diversity of soil invertebrates can differ many times from their original values (Kuznetsov et al., 2017; Kuznetsov and Ryzhova, 2019). A variety of anthropogenic activities suppress the abundance and diversity of soil invertebrate communities. The direction and magnitude of the response depends on the taxonomic group (Nahmani and Lavelle, 2002; Pey et al., 2014; Pouyat et al., 2015; Santorufo et al., 2012). For example, isopods in urban soils show a negative abundance response to heavy metal pollution (Pouyat et al., 2015). Air pollutants and pesticides affect soil properties, which also negatively affects the abundance of invertebrates (Byrne et al., 2008; Fedoniuk et al., 2020; Gan and Wickings, 2017; S. Joimel et al., 2016; Joimel et al., 2017; Peck, 2009; Smetak et al., 2007).

The soil invertebrates respond sensitively to disturbance of soil regimes, so they are valuable biological indicators of the level of anthropogenic transformation of ecosystems (Nahmani and Lavelle, 2002; Santorufo et al., 2012). 
Molluscs are an important component of terrestrial ecosystem communities (Kramarenko et al., 2016). Their biological features allow maintaining high diversity and abundance under conditions of anthropogenic impact. These animals are quite common in urban environments. However, hotspots of high abundance and diversity of molluscs are extremely limited by the influence of a variety of environmental factors, a mosaic of which is observed in the urban environment. The habitat preference of terrestrial molluscs depends on vegetation, soil type, moisture level, and the degree of anthropogenic transformation of ecosystems. The preferential importance of environmental factors varies at different levels of the spatial hierarchy. At the broad spatial level, among the climatic factors, temperature and humidity have the greatest influence on terrestrial molluscs. Other climatic factors affect molluscs much less or indirectly, but due to changes in humidity and temperature (Kunakh et al., 2018; Martin and Sommer, 2004b; Millar and Waite, 1999; Pakhomov et al., 2019). At the landscape level, calcium concentration and its dependent $\mathrm{pH}$ value are the most significant soil parameters that affect snails (Hotopp, 2002; Schilthuizen et al., 2003). The soil moisture was also found to be a significant factor in the diversity of the terrestrial snail fauna (Čejka and Hamerlík, 2009; Martin and Sommer, 2004a; Silvan et al., 2000). The degree of anthropogenic transformation of an ecosystem can be assessed by studying the diversity of land snail communities and the response of individual species to environmental factors (Douglas et al., 2013). A number of models that best explain the distribution of mollusc species abundance were shown to be species-specific and soil typespecific and tended to be invariant over time (Kunakh et al., 2020; Pakhomov et al., 2019; Zhukov et al., 2016a). Hutchinson's concept was shown to be useful for the simulation of the ecological niche of the mollusc in the biotopes resulting from reclamation of degraded lands (Kunakh et al., 2020; Kunakh et al., 2018; Teluk et al., 2020; Yorkina et al., 2018; Yorkina et al., 2019; Yorkina, 2016; Yorkina et al., 2019).

The aim of this study is to investigate the role of recreation as a factor in transforming the living conditions of soil micromolluscs in a park environment in an urban landscape. The hypothesis is that recreational exposure changes the hierarchical organization of the spatial distribution of micromolluscs.

\section{Materials and Methods}

\section{Study area and mollusc sampling}

An experimental polygon was laid down in Novooleksandrivskiy Park (Melitopol, Ukraine) that represented 7 transects with 18 test points in each (Figure 1). The interval between points in transect, as well as the interval between transects, was 3 meters. The total area of the polygon was $1,134 \mathrm{~m}^{2}$. Sampling was conducted in October 2020. In each sampling point, a soil sample of cylindrical shape (diameter $-9 \mathrm{~cm}$, height $-8 \mathrm{~cm}$, volume $\approx 500 \mathrm{~cm}^{3}$ ) was taken from the surface to a depth of $8 \mathrm{~cm}$. From this sample, 10 soil sub-samples weighing 10 grams were taken. Each sample was examined with a dissecting needle to collect micromolluscs (Yorkina et al., 2018).

\section{Soil variables}

Measurement of soil penetration resistance was carried out in the field using a hand penetrometer Eijkelkamp, to a depth of $50 \mathrm{~cm}$ at intervals of $5 \mathrm{~cm}$ (Zhukov and Zadorozhnaya, 2016). The average error of the measurement results of the device is $\pm 8 \%$. The measurements were made by a cone with a crosssectional dimension of $2 \mathrm{~cm}^{2}$. Within each measurement point, the soil penetration resistance was made in a single replication. To measure the electrical conductivity (EC) of the soil in situ, the sensor HI 76305 was used (Hanna Instruments, Woonsocket, R. I.) (Scoggins and van Iersel, 2006). This sensor works in conjunction with the portable device HI 993310. Soil water content was measured under field conditions using a dielectric digital moisture meter MG-44 (vlagomer.com.ua). The aggregate structure was evaluated in accordance with the 'Soil Sampling and Methods of Analysis' recommendations. The percentage content of such fractions was established: $<0.25,0.25-0.5,0.5-1,1-2,2-3,3-5,5-7,7-10,>10 \mathrm{~mm}$. The soil bulk density estimated by the core method (Al-Shammary et al., 2018). 


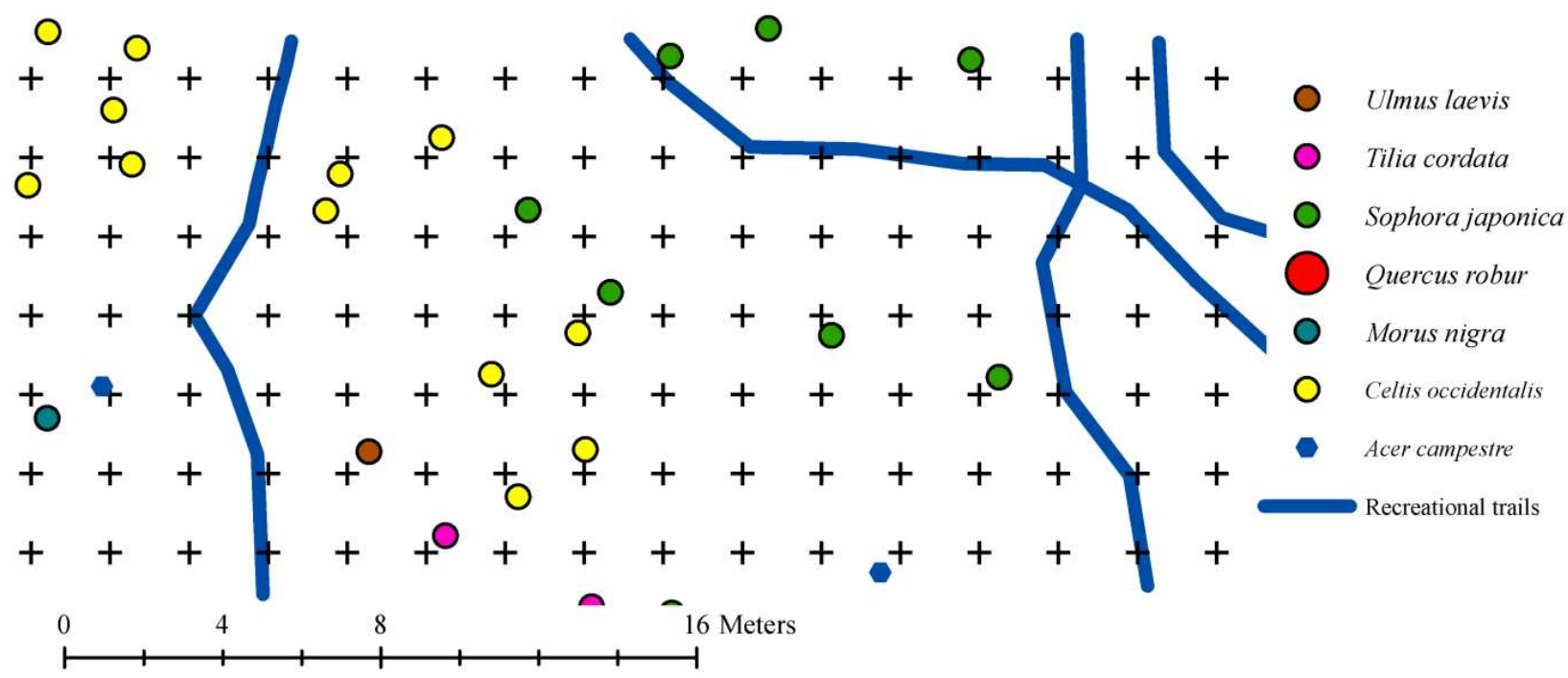

Figure 1: The experimental polygon within Novooleksandrivsky Park (Melitopol): crosses show sampling points; circles show location of the trees and bushes within the polygon; $x$-axis and $y$-axis are the local coordinates of the polygon.

\section{Statistical analysis}

The Redundancy Analysis (RDA) was applied to examine the variance in the species composition of molluscs (Rao, 1964). The soil penetration resistance, soil electrical conductivity, soil moisture and soil bulk density were logarithmically transformed before analysis. The significance of RDA global model was first tested. The soil models were based on the forward selection and were built with double stopping rule (alpha significance level and the $R_{a d j}^{2}$ calculated using all explanatory variables) (Blanchet et al., 2008). The variables were retained only with a significant relationship to community composition ( $p<0.05,9999$ permutations). The models' marginal effect was computed, in which each selected soil variable was used separately as a predictor of community composition and the significance of all the models was tested and $R_{a d j}^{2}$ was extracted. The geographic coordinates of sampling locations were used to generate a set of orthogonal eigenvector-based spatial variables (dbMEMs), each of them representing a pattern of particular scale within the extent of the sampling area (Borcard and Legendre, 2002). The forward-selection procedure on partial RDAs was applied to the subset of spatial variables. The significance of soil models was tested by the Monte Carlo permutation test (9999 permutations). In the next phase of the study, the dbMEMs were forward-selected directly on community data to explore patterns in community variation by variance partitioning between environmental and spatial influence. The significance of pure spatial and environmental fractions was tested by Monte Carlo permutation tests with 9999. The scalogram approach was applied to inspect in detail the spatial scaling of community variation. To do this, the two sets of RDA analyses were carried out with each of the dbMEM variables as a predictor. As a response variable, the first set of RDA analyses used raw species data, while the second set used residuals of the environmental model in which forward-selected environmental variables acted as predictors (Chudomelová et al., 2017). From each RDA we extracted $R_{a d j}^{2}$ for individual dbMEMs and plotted them into juxtaposed bar plots (Chang et al., 2013).

All statistical analyses were conducted in R (v. 3.5.0., R Foundation for Statistical Computing, Vienna, AT), using the following packages: vegan (v. 2.5-2, https://CRAN.R-project.org/package=vegan) (Oksanen $e t$ al., 2019), adespatial (v. 0.3-2. https://CRAN.R-project.org/package=adespatial) for the forward selection and for the generation of spatial filters (Dray et al., 2018). 


\section{Results}

A total of 787 individuals of Vallonia pulchella (Muller 1774), 193 individuals of Cochlicopa lubrica (Muller 1774), and 74 individuals of Acanthinula aculeata (Muller 1774) were collected. The samples with Vallonia pulchella represented $88.9 \%$ of all samples, the samples with Cochlicopa lubrica represented $81.7 \%$ of all samples, and the samples with Acanthinula aculeata represented $42.1 \%$ of all samples (Figure 1). The maximum number of Vallonia pulchella individuals per sample was 24, Cochlicopa lubrica - had 7 individuals per sample, and Acanthinula aculeata - contained 3 individuals per sample (Figure 2). The abundance of the mollusc was distributed unevenly over the studied area (Figure 3 ). The aggregation index indicates an aggregated spatial distribution of Vallonia pulchella and Cochlicopa lubrica and a neutral distribution of Acanthinula aculeata (Figure 4).
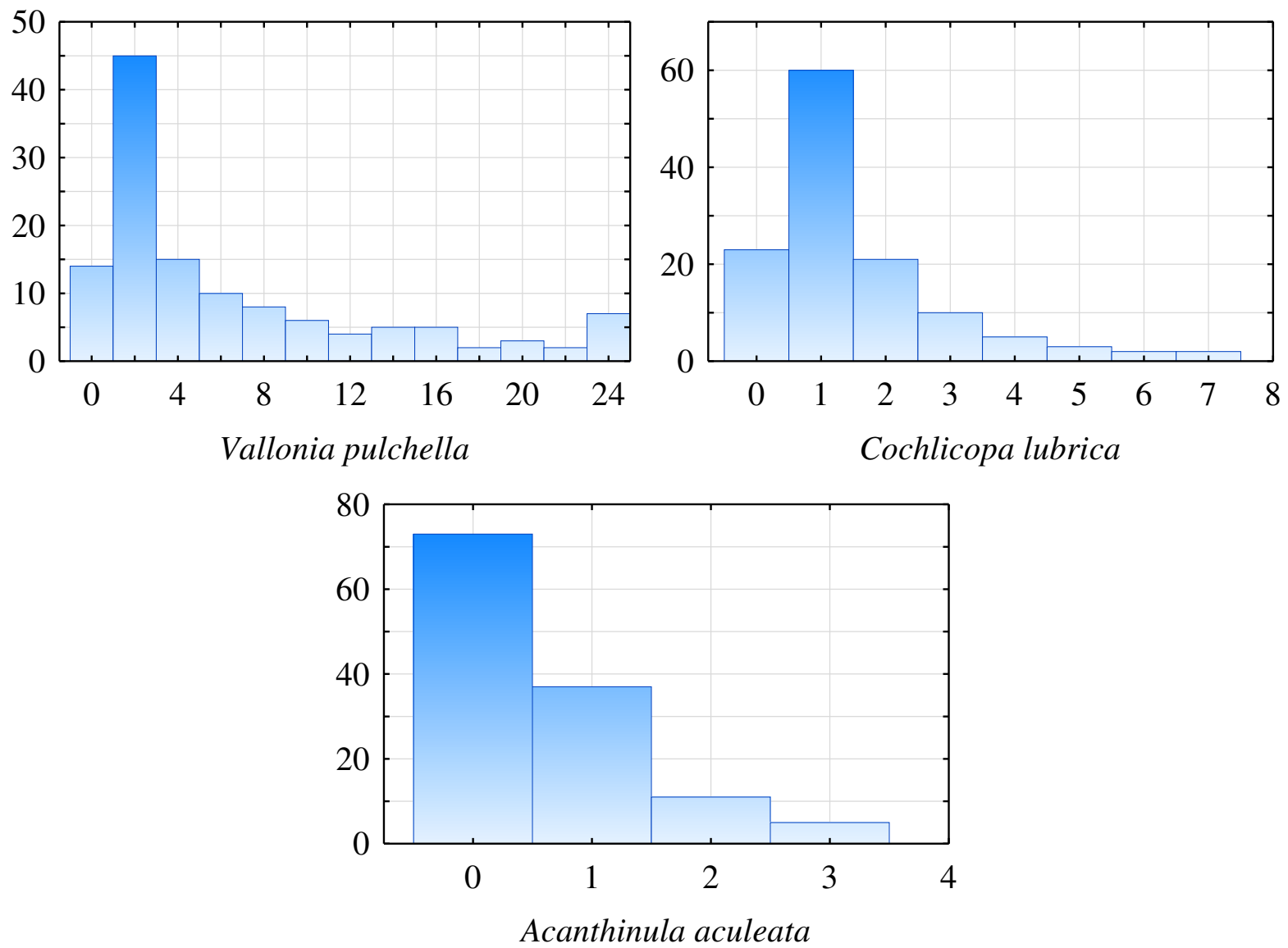

Figure 2: Histograms of mollusc abundance distribution. Abscissa axis - the number of individuals in the soil sample, ordinate axis - the number of occurrences.

The set of soil properties explained $24.7 \%$ of the variation in the mollusc community $(F=2.87, p=0.001)$. After the forward selection procedure, such variables as the soil mechanical resistance at a depth of 5-10 $\mathrm{cm}$, the proportion of aggregates of size $0.25-0.5,2-3$, and $3-5 \mathrm{~mm}$ were chosen as the most informative for describing the structure of the mollusc community. These soil variables together were able to explain $18.4 \%$ of mollusc community variation $(F=8.12, p=0.001)$. The distance from trees was able to explain $6.8 \%$ of mollusc community variation $(F=10.12, p=0.001)$. The distance from recreational pathways was able to explain $12.2 \%$ of the variation in the mollusc community $(F=18.4, p=0.001)$.

The spatial patterns were modeled by 62 dbMEM spatial eigenfunctions. These dbMEM spatial eigenfunctions were able to explain $54.2 \%$ of mollusc community variation $(F=3.39, p=0.001)$. The 
forward selection procedure allowed the identification of the 13 most informative dbMEM spatial eigenfunctions, which were variables $1,2,3,6,9,10,11,14,23,26,34,53$, and 61 . Together they were able to explain $27.9 \%$ of the variation in the mollusc community $(F=4.73, p=0.001)$. All of the predictors considered together can explain $65.4 \%$ of the variation in the mollusc community (Figure 5). The pure influence of soil properties on molluscs is not significant $(1.1 \%)$. The influence of soil is spatially structured $(11.9 \%)$ and also spatially structured by trees $(10.9 \%)$. The pure influence of spatial factors is $30.1 \%$. The pure influence of trees is $1.5 \%$. Also the influence of trees is manifested through the structuring of the soil properties $(2.3 \%)$.
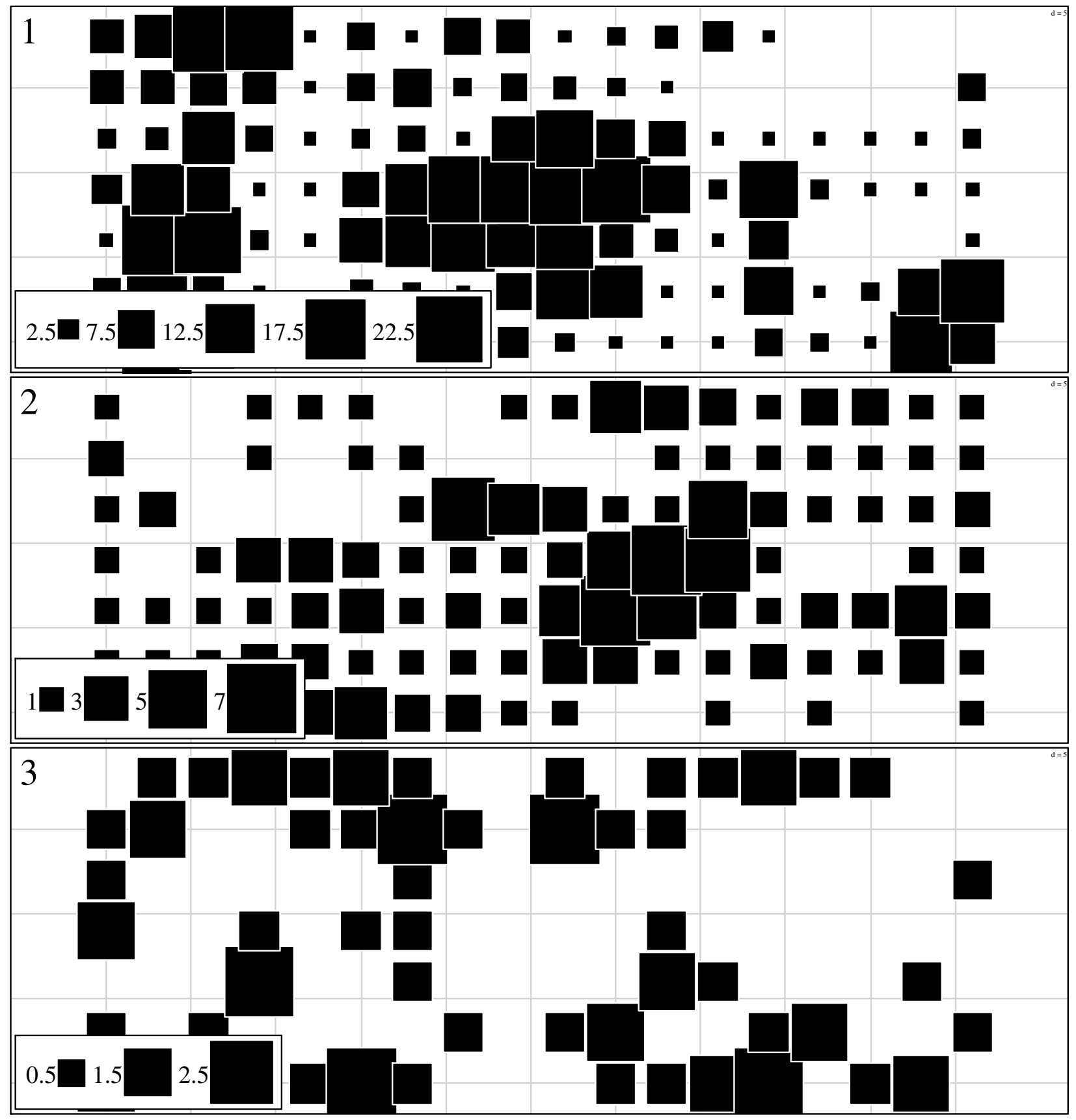

Figure 3: Spatial distribution of molluscs: 1 - Vallonia pulchella, 2 - Cochlicopa lubrica, 3 - Acanthinula aculeata. Axis of abscissa and ordinates are local coordinates. 
The role of recreational paths manifests itself through the influence on soil properties $(6.4 \%)$, through the spatial structuring of soil properties $(4.5 \%)$ and through the spatial structuring of soil properties under the influence of the tree stand $(10.9 \%)$.

The dbMEM spatial eigenfunctions with different ordinal numbers (the larger the ordinal number, the greater the characteristic frequency of the oscillatory process which the function models) made different contributions to the variation of the mollusc community structure (Figure 6). Accordingly, broad-scale, medium-scale, and fine-scale spatial components of community variation were distinguished. The application of the soil properties as covariates did not significantly alter the nature of the spatial patterns. The distance from recreational trails conditioned the large-scale component. The use of distance from the recreational as a covariate revealed an additional spatial pattern of variability in mollusc community structure. Paths indicated that recreational influence was a source of "disinformation" and its removal allowed previously hidden patterns to be revealed predominantly at the fine-scale range.

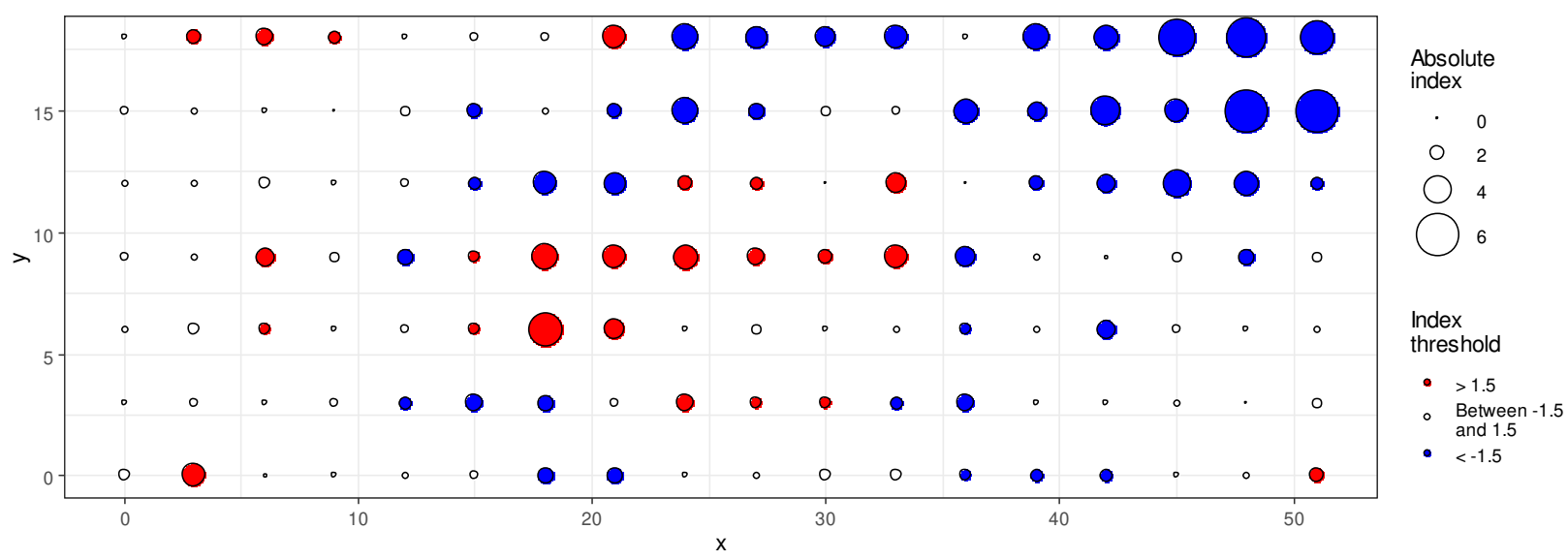

A

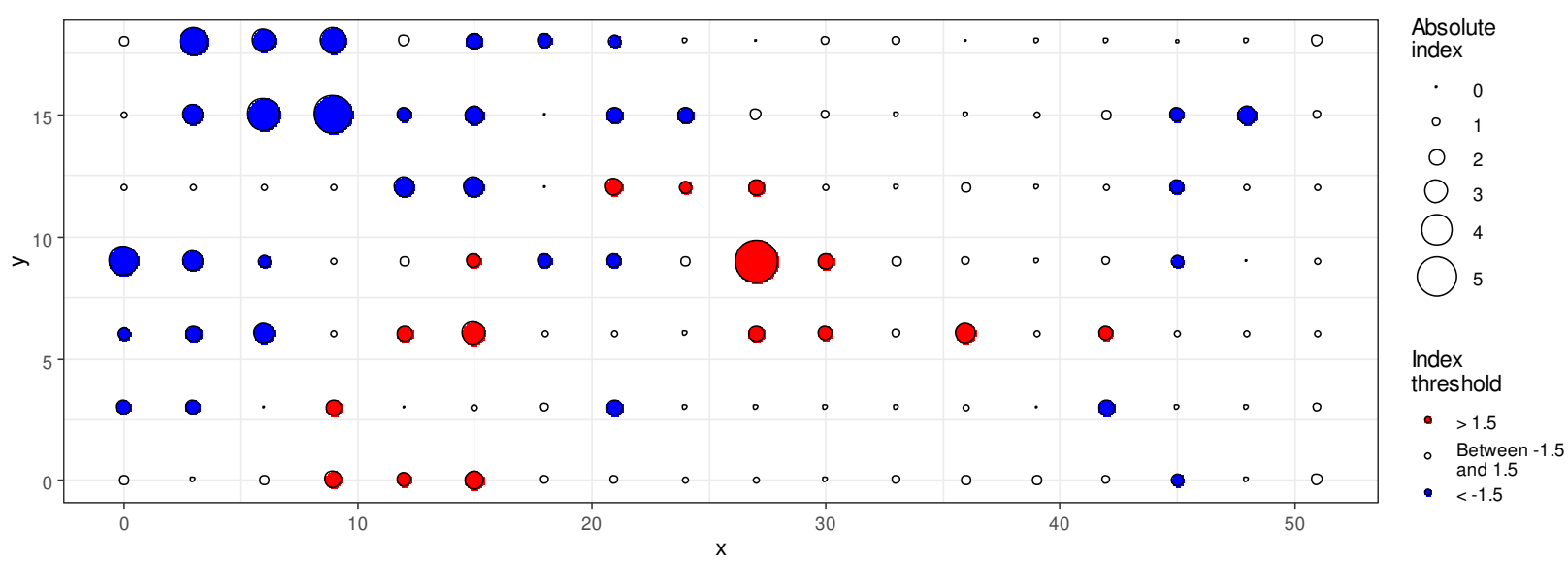

B 


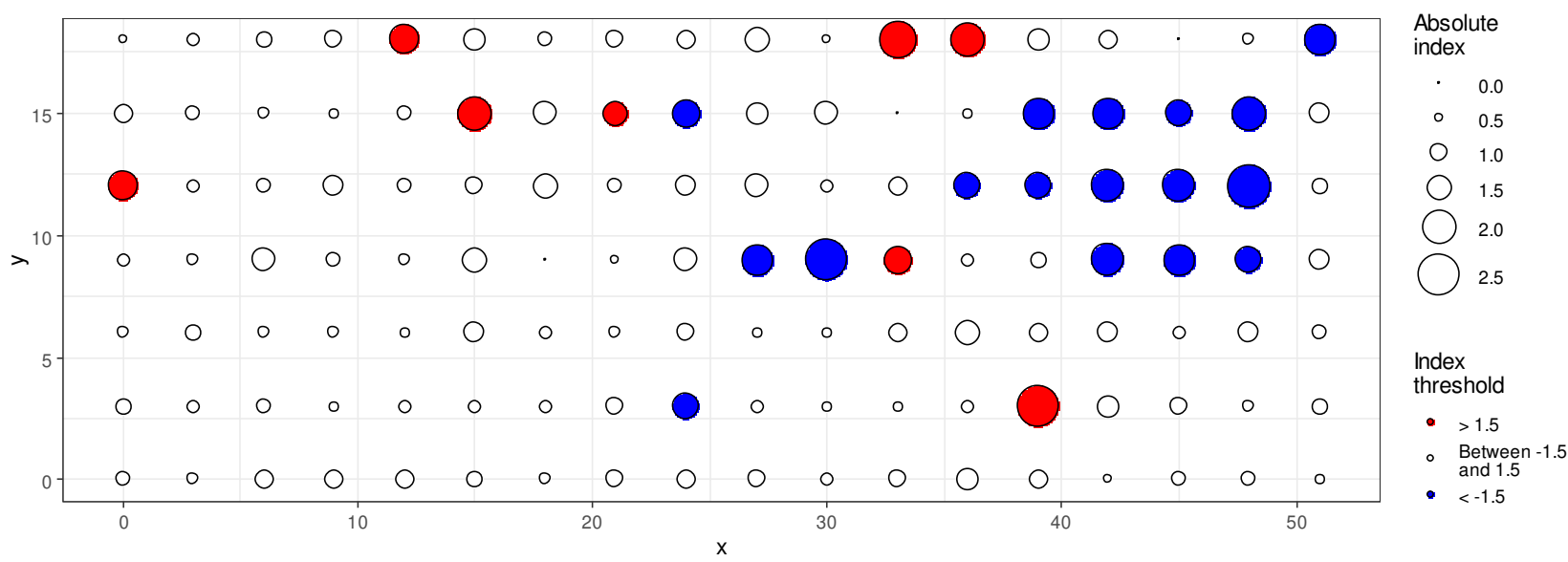

$\mathrm{C}$

Figure 4: Red-blue plots for detecting clusters in mollusc abundance data: A - Vallonia pulchella $\left(I_{a}=\right.$ 1.777, $\left.P_{a}<0.001\right), \mathrm{B}-$ Cochlicopa lubrica $\left(I_{a}=1.365, P_{a}=0.05\right), \mathrm{C}-$ Acanthinula aculeata $\left(I_{a}=1.068\right.$, $\left.P_{a}=0.28\right)$.

A similar argument can be made for the influence of trees, but this influence had a predominant manifestation in the medium-scale range. The pure spatial pattern of variability in the mollusc community structure had distinct broad-scale and fine-scale components.

The broad-scale pattern of variation in mollusc community structure was modeled using dbMEM spatial eigenfunctions $1,5,6,9,10,14,16,19$. The broad-scale spatial pattern was able to describe $25.3 \%$ of the variation in mollusc community structure (Table 1). The medium-scale pattern of variation in mollusc community structure was modeled using dbMEM spatial eigenfunctions $23,26,32,36,37$. The mediumscale spatial pattern described $10.5 \%$ of clam community structure variation.

The detailed-scale pattern of variation in mollusc community structure was modeled using dbMEM spatial eigenfunctions $46,52,61$. The detailed spatial pattern described $4.7 \%$ of mollusc community structure variation.

The spatial features of the broad-scale and partly medium-scale patterns were largely driven by soil properties (Figure 7). The broad-scale component was driven by distance from trees and distance from recreational paths. This pattern also reflected variability in soil penetration resistance, aggregate structure, electrical conductivity, moisture, and soil density. The medium-scale pattern had a component that reflected variability in soil aggregate composition and a component that was independent of soil properties. The detailed-scale component reflected variability in the clam community, which was independent of soil properties. The variability of the mollusc community was mainly due to the variability in the abundance of Cochlicopa lubrica and Acanthinula aculeata (Figure 8). 

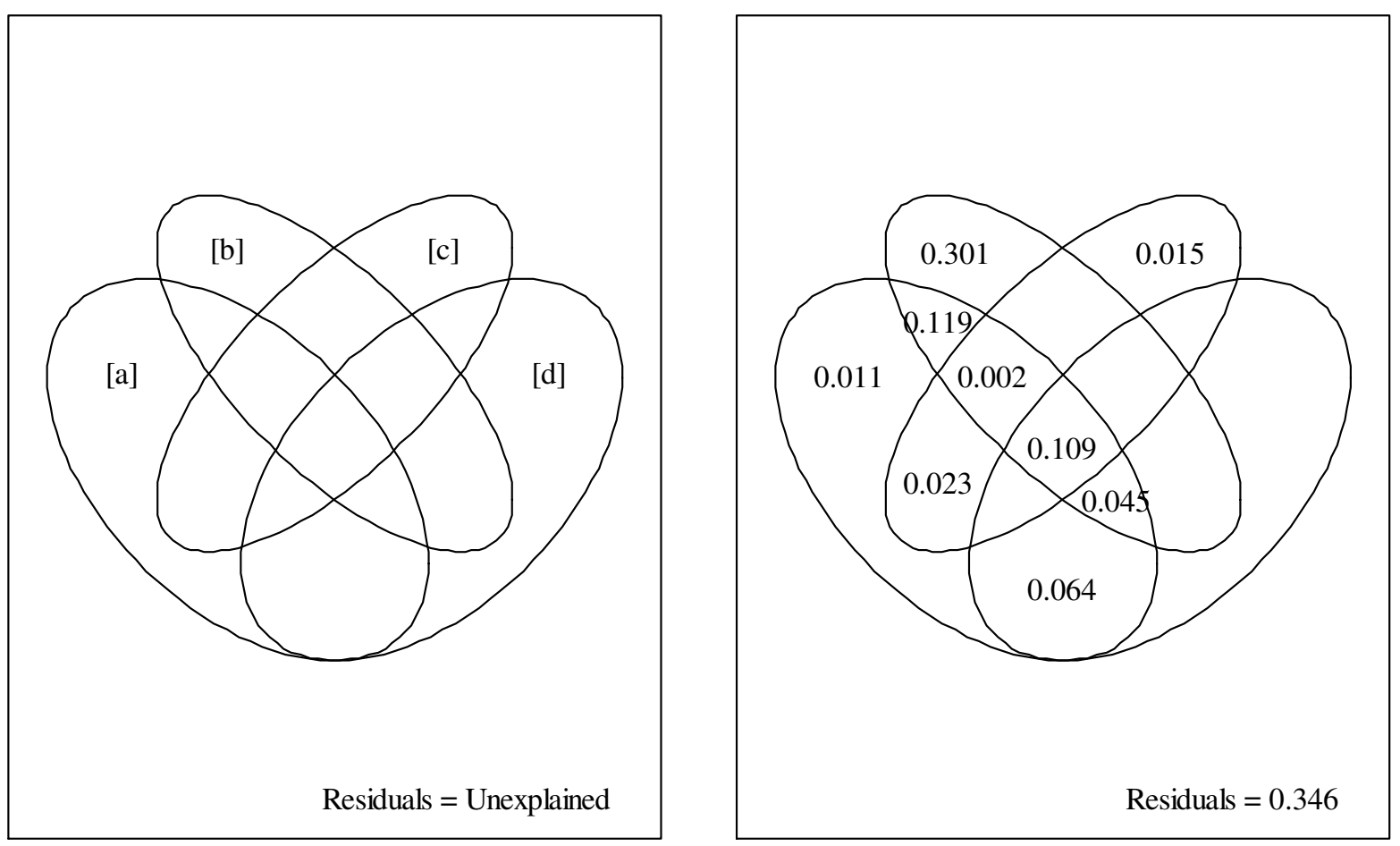

Values $<0.001$ not shown

Figure 5: Variance partitioning between spatial, soil, plant and tree distance explanatory variables Notes: [a] - variation explained solely by soil variables; [b] - variation captured by spatial (dbMEM) variables corresponds to pure space (residual spatial component); [c] - variation captured by distances from tree stems; [d] - explained solely by distances from tree recreation pathways. The intersection of the ellipses corresponds to the variations explained by the respective sources together. All the variance fractions shown are significant $(p<0.001)$.

\section{Discussion}

The ecological factors influencing the distribution of species are usually spatially structured, so the species community also has a spatial structure (Andrushenko and Zhukov, 2016; Pinkina et al., 2019; Thuiller et al., 2004; Zhukov et al., 2015). The micromollusc community in the park plantation in the city of Melitopol is represented by three species, among which Vallonia pulchella significantly dominates, Cochlicopa lubrica is significantly less abundant and Acanthinula aculeata almost 10 times less abundant. Factors such as recreational pressure and spatial location of trees may be responsible for the aggregated distribution of mollusc species (Kunakh et al., 2018). These factors influence patterns of the spatial variability of soil properties, which, in turn, acts as a driver of the micromollusc community structure. An obvious consequence of recreational load is soil compaction. The spatial heterogeneity of soil properties, which are induced by the spatial distribution of plants, is a factor that organizes the spatial distribution of soil animals. In this respect, the tree layer, the structure of the herbaceous and dead cover is important. This transformation leads to a set of other changes in soil properties and regimes. 

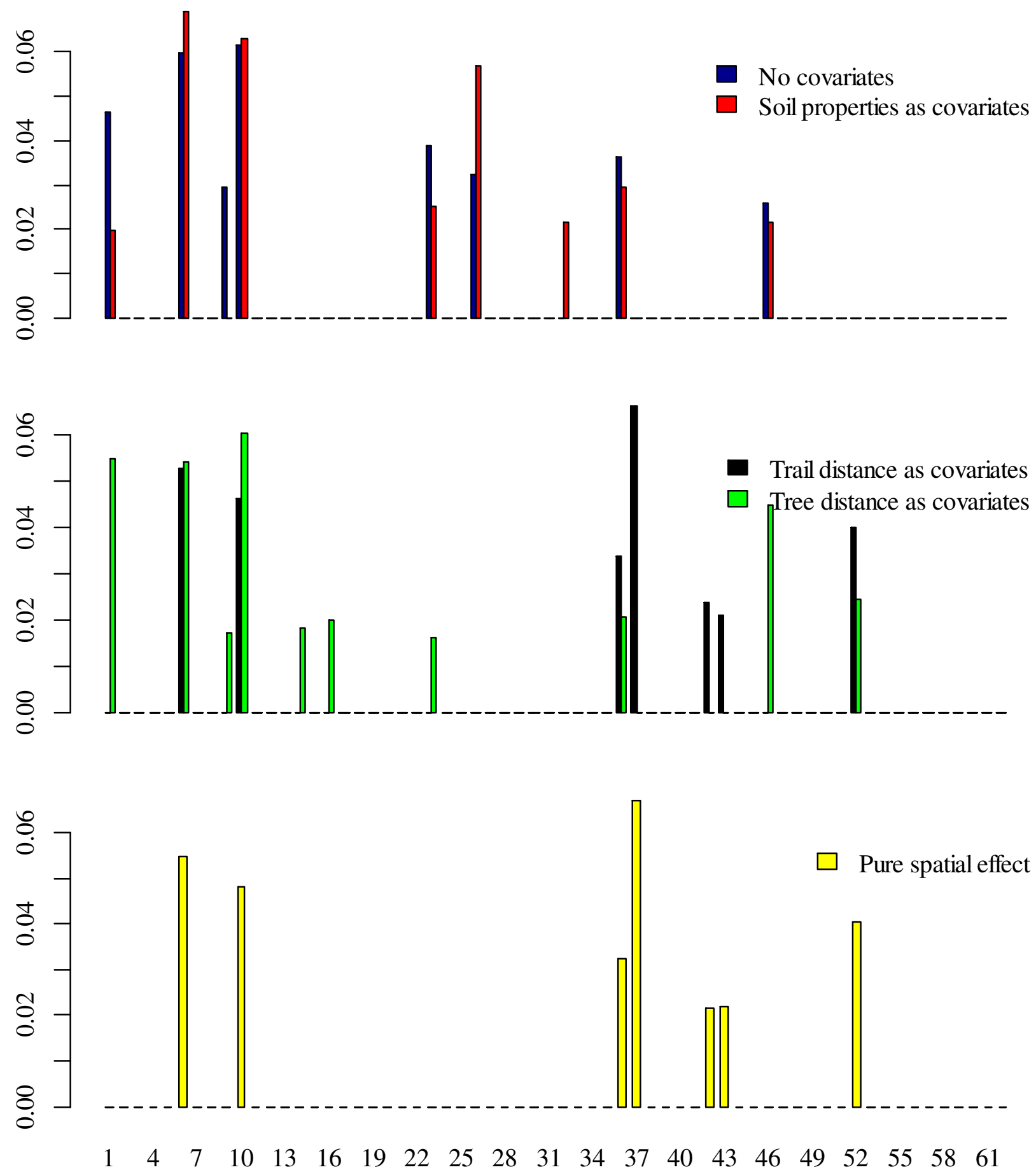

Figure 6: Scalograms illustrating the scaling of spatial structured variation in community data (No variables as covariates, blue bars) and soil models (red bars), residuals of the trail distance models (black bars), tree distance models (green bars) and pure spatial effect (yellow bars). The value of $R_{a d j}^{2}$ is the variation explained by individual dbMEM variables. The dbMEMs are ordered decreasingly according to the scale of spatial patterns they represent ( $x$-axis is the number of dbMEM; dbMEM 1 represents the broadest scale, dbMEM 61 represents the finest scale).

Soil with increased density presents less space for both the storage of soil moisture and the storage of soil air. The available soil water is an important environmental factor for the biota of anthropogenically transformed lands. Obviously, a decrease in the amounts of these two most important soil parameters leads 
to a deterioration of the living conditions of soil animals, including micromolluscs. The recreational compaction of soil increases soil penetration resistance mainly in the upper soil horizons, which are predominantly inhabited by soil animals. Soil penetration resistance depends on soil moisture, soil organic matter content, the composition of accumulated cations, the ratio of structural aggregates, and, very noticeably, on the granulometric composition (Bécel et al., 2012; Zhukov, 2015b). All this makes the use of soil penetration resistance in both soil-genetic and agronomic studies promising. From the soil-physical factors influencing soil penetration resistance, the water content of the soil and its energy state should come first (Young et al., 2000). Next from the physical factors are the granulometric composition, density of the composition, structural composition, pore size and the ratio of large and fine pores, and others (Bennie and du Burger, 1988; Bennie and Krynauw, 1985; Quiroga et al., 1999). The factors listed have a decisive influence on the cone strength index and the ability of the soil to compress. The correlation between the clay and sand content of the soil and the change in the so-called cone index value (i.e., soil resistance) due to its wetting was revealed (Arriaga et al., 2011). As one would expect, the soil resistance increases with decreasing soil moisture regardless of the clay-sand ratio. However, such processes in the soil as cementation and crust formation, and dynamics of density of the soil during tillage made adjustments to the established dependencies. In particular, the data collected showed that the cone strength index in soils of different genesis is not the same for the same values of density and moisture. Soils of light granulometric composition as well as well humus-covered, structured, freshly ploughed soils with increasing clay particles in the granulometric fraction have the least penetration resistance.

Increased soil density has a negative effect on the living conditions of higher plants because it limits the development of plant root systems. Living conditions for lower plants, including algae, which are a trophic target for micromolluscs, are also deteriorating (Maamar et al., 2018). Thus, recreation is an essential factor that structures the spatial organization of the community of soil micromolluscs. Molluscs may also be the cause of the spatial heterogeneity of environmental regimes. The substantial contribution of snails to the nitrogen cycle was proved in nitrogen-limited ecosystem which can be a source of spatial heterogeneity of the higher plant production (Jones et al., 1994; Jones and Shachak, 1990). Some terrestrial gastropod communities cause of the changes in the content of the nitrogen and phosphorus in the soil. This result reveals that the spatial and temporal dynamics of plant communities are dependent on the detritivore food chain structure (Thompson et al., 1993).

The aggregates are the main component of the soil structure, which allows to measure its physical state as an environment for living organisms (Kunah et al., 2019). Soil structure affects soil moisture content, infiltration capacity, erodibility, circulation of nutrients, stabilization of organic matter, root penetration, productivity of natural plant communities and crop yields (Bronick and Lal, 2005; Chaplot and Cooper, 2015; Chrenková et al., 2014). The aggregate stability is used as an indicator of the soil structure (Mustafa et al., 2020). The structure and stability of soil aggregates is most important to consider as a condition for increasing agronomic productivity and reducing soil erosion (Xu et al., 2016). Aggregation of soil was studied mainly in agricultural context. The role of tillage, soil texture and the presence of carbon in the agricultural land as factors that influence the aggregate structure was estimated (Wilpiszeski et al., 2019; Zhang et al., 2012). In the process of land reclamation, it is important to select optimal management strategies to create not only the desired vegetation cover, but also to promote the preservation of macroaggregate structure in soils to improve long-term nutrient supply and physical properties of the soil (Klimkina et al., 2018; Wick et al., 2009, 2016). Aggregation processes in soil are the result of interaction of a number of physical, chemical and biological factors with the complex feedback mechanisms (Oades and Waters, 1991; Rivera and Bonilla, 2020; Sodhi et al., 2009). The soil aggregation is considered as a process regulated by the biota (Duchicela et al., 2013; Rillig and Mummey, 2006; Tisdall and Oades, 1982). In soils where organic matter is a major aggregate binding agent, a link can be established between aggregate size distribution and soil's biological functions. The role of biodiversity in soil aggregation is of particular interest (Delgado-Baquerizo et al., 2017; Wagg et al., 2014). There are different mechanisms of soil biota influencing the aggregation of soil (Lehmann and Kleber, 2015). Bacteria are known to be able to synthesize a biopolymer that acts as a binder to form aggregates (Deng et al., 2015), and the mushroom mycelium can 
entangle the soil particles to keep them together (Griffiths, 1965). The earthworms, insect larvae and other large soil animals may stabilize the aggregate structure (Bertrand et al., 2015; Fonte et al., 2007; Mummey et al., 2006; Zhukov et al., 2016b). Soil saprophages consume the soil and mix it with the intestinal contents (Maraun et al., 2003; Ponge, 1991). After digestion, the resulting mixture takes the form of a highly structured formation such as casts or coprolites (Tisdall and Oades, 1982).

Table 1: Descriptive statistics of the soil properties and distances from the trees and from the route trails

\begin{tabular}{|c|c|c|c|c|c|c|c|}
\hline \multirow[b]{2}{*}{ Variables } & \multirow[b]{2}{*}{$\begin{array}{l}\text { Mean } \pm \\
\text { st.error }\end{array}$} & \multicolumn{2}{|c|}{$\begin{array}{l}\text { Broad-scale, } \\
R_{a d j}{ }^{2}=0.25\end{array}$} & \multicolumn{2}{|c|}{$\begin{array}{l}\text { Medium-scale, } \\
R_{a d j}^{2}=0.11\end{array}$} & \multicolumn{2}{|c|}{$\begin{array}{l}\text { Fine-scale, } \\
R_{a d j}^{2}=0.05\end{array}$} \\
\hline & & $\begin{array}{l}\text { CCA1 } \\
F= \\
39.3, \\
p= \\
0.001\end{array}$ & $\begin{array}{l}\text { CCA2 } \\
F=15.1 \\
p=0.024\end{array}$ & $\begin{array}{l}\text { CCA1 } \\
F=18.0 \\
p=0.001\end{array}$ & $\begin{array}{l}\text { CCA2 } \\
F=2.1, \\
p=0.818\end{array}$ & $\begin{array}{l}\text { CCA1 } \\
F=8.8, \\
p=0.003\end{array}$ & $\begin{array}{l}\text { CCA2 } \\
F=0.38 \\
p=0.943\end{array}$ \\
\hline
\end{tabular}

Soil penetration resistance at a depth of, $\mathrm{cm}$ in $\mathrm{MPa}$

\begin{tabular}{|c|c|c|c|c|c|c|c|}
\hline $0-5$ & $2.97 \pm 0.09$ & 0.35 & 0.22 & - & - & - & - \\
\hline $5-10$ & $4.72 \pm 0.12$ & 0.35 & 0.20 & - & - & - & - \\
\hline $10-15$ & $6.10 \pm 0.14$ & 0.35 & 0.21 & - & - & - & - \\
\hline $15-20$ & $6.93 \pm 0.14$ & 0.27 & - & - & - & - & - \\
\hline $20-25$ & $7.67 \pm 0.12$ & - & 0.21 & - & - & - & - \\
\hline $25-30$ & $8.19 \pm 0.11$ & - & - & - & - & - & - \\
\hline $30-35$ & $8.35 \pm 0.08$ & - & - & - & - & - & - \\
\hline $35-40$ & $8.66 \pm 0.08$ & - & - & - & - & - & - \\
\hline $40-45$ & $8.48 \pm 0.09$ & - & - & - & - & - & - \\
\hline $45-50$ & $8.17 \pm 0.09$ & - & - & - & - & - & - \\
\hline \multicolumn{8}{|c|}{ Aggregate fraction, in $\%$} \\
\hline$>10 \mathrm{~mm}$ & $11.25 \pm 0.37$ & - & - & -0.38 & - & - & - \\
\hline $7-10 \mathrm{~mm}$ & $7.23 \pm 0.09$ & - & - & -0.41 & - & - & - \\
\hline $5-7 \mathrm{~mm}$ & $8.08 \pm 0.12$ & -0.30 & -0.19 & - & - & - & - \\
\hline $3-5 \mathrm{~mm}$ & $10.68 \pm 0.17$ & -0.40 & - & - & - & - & - \\
\hline $2-3 \mathrm{~mm}$ & $9.58 \pm 0.18$ & -0.32 & - & 0.21 & - & - & - \\
\hline $1-2 \mathrm{~mm}$ & $13.18 \pm 0.25$ & - & - & - & - & - & - \\
\hline $0.5-1 \mathrm{~mm}$ & $2.45 \pm 0.04$ & - & - & - & - & - & - \\
\hline $0.25-0.5 \mathrm{~mm}$ & $12.59 \pm 0.26$ & 0.24 & - & - & - & - & - \\
\hline$<0.25 \mathrm{~mm}$ & $25.00 \pm 0.40$ & 0.23 & - & 0.27 & - & - & - \\
\hline \multicolumn{8}{|c|}{ Other soil properties } \\
\hline $\begin{array}{l}\text { Electrical } \\
\text { conductivity, } \\
\mathrm{dSm} / \mathrm{m}\end{array}$ & $0.07 \pm 0.001$ & -0.19 & - & - & - & - & - \\
\hline $\begin{array}{l}\text { Soil moisture, } \\
\%\end{array}$ & $9.31 \pm 0.10$ & -0.19 & -0.18 & - & - & - & - \\
\hline $\begin{array}{l}\text { Soil bulk } \\
\text { density, } \mathrm{g} / \mathrm{cm}^{3}\end{array}$ & $1.10 \pm 0.01$ & 0.34 & 0.19 & - & - & - & - \\
\hline \multicolumn{8}{|l|}{ Distance, $\mathrm{m}$} \\
\hline From the trees & $2.54 \pm 0.15$ & 0.24 & 0.24 & - & - & - & - \\
\hline $\begin{array}{l}\text { From the route } \\
\text { trails }\end{array}$ & $3.25 \pm 0.22$ & -0.41 & - & - & - & - & - \\
\hline
\end{tabular}


The spatial variation of soil aggregate structure can influence the organization of the soil macrofauna community. The soil aggregates also help form the unique ecological isolation of the microbial community in the soil (Rillig et al., 2017). Soil aggregates can serve as a refuge for the microbes from the predators (Rillig et al., 2017). There are practically no research highlighting influence of the soil aggregate structures on the functional features of the mollusc populations. It is possible, that the organic substances in the soils indirectly impact on the molluscs, which requires the deep understanding of the structure and formation of the aggregates. The aggregate composition of the soil also changes in accordance with the changes in the soil density. More solid soils are represented either by relatively coarse aggregates larger than $10 \mathrm{~mm}$ or by fine aggregates that effectively fill in the gaps between the coarse ones. An optimal water and air regime of soils can be maintained with aggregates between 0.25 and $7 \mathrm{~mm}$ in size. The results of this study indicate a positive effect on micromolluscs of increasing the proportion of aggregates of $0.25-5 \mathrm{~mm}$ size.

Trees are also an important factor that structures ecological conditions (Zhukov, 2015a; Zhukov et al., 2016). The crown of trees regulates the inflow of solar energy to the soil surface, which determines the temperature regime of the soil and the intensity of moisture evaporation from the soil surface. The root system of trees has a significant capacity to change soil properties. It should be noted that trees and recreational paths are antagonists: spontaneous paths are formed at some distance from the trunks of tree plants. Thus, a structuring gradient is formed: recreational pathway-tree plants.

This gradient determines the broad-scale component of the spatial variability of the molluscan community. The broad-scale nature implies a significant impact zone in the radial direction from the trees, which is quite consistent, as commensurate with the spatial distribution of above-ground and below-ground phytomass of the tree plant. Also widespread is the impact of recreational load, which is not trivial. This result indicates that the effects of recreational load extend well beyond the geometric boundaries of recreational pathways. In part, the widespread nature may be due to the antagonism of trees and walkways and may be a consequence of the structuring influence of the park stand. Nevertheless, the direct impact of recreation is a significant structuring factor that has a significant extent that extends well beyond the footpaths. There is a consistent widespread pattern of recovery of normal values of soil density, moisture, and aggregate composition as one moves away from the walkways. Such changes are also associated with the recovery of micromollusc abundance; and sharp decrease was noted for all species near the walkway.

Medium-scale patterns of variation in the mollusc community are due to either soil conditions, which primarily depend on soil aggregate composition, or to causes that do not depend on measured soil properties. In turn, it may be due to either other soil properties that are not measured or to causes that are neutral in nature. Medium-scale patterns that are dependent on soil properties may most likely result from natural variability in soil properties, which is determined by mechanisms other than recreational load. Thus, natural and anthropogenic patterns have different scale levels of manifestation. Anthropogenic patterns are broadscale, while natural patterns are both broad-scale and medium-scale. The fine-scale patterns are independent of measured soil properties. The fine-scale patterns can either be caused by other soil properties that were not measured in this study. The most attractive explanation is the structuring of the community as a result of inter-species interactions. For this reason, the emergence of the structural organization of the community may not have a significant extent in view of the local nature of inter-specific interactions, which probably explains its detailed nature. 

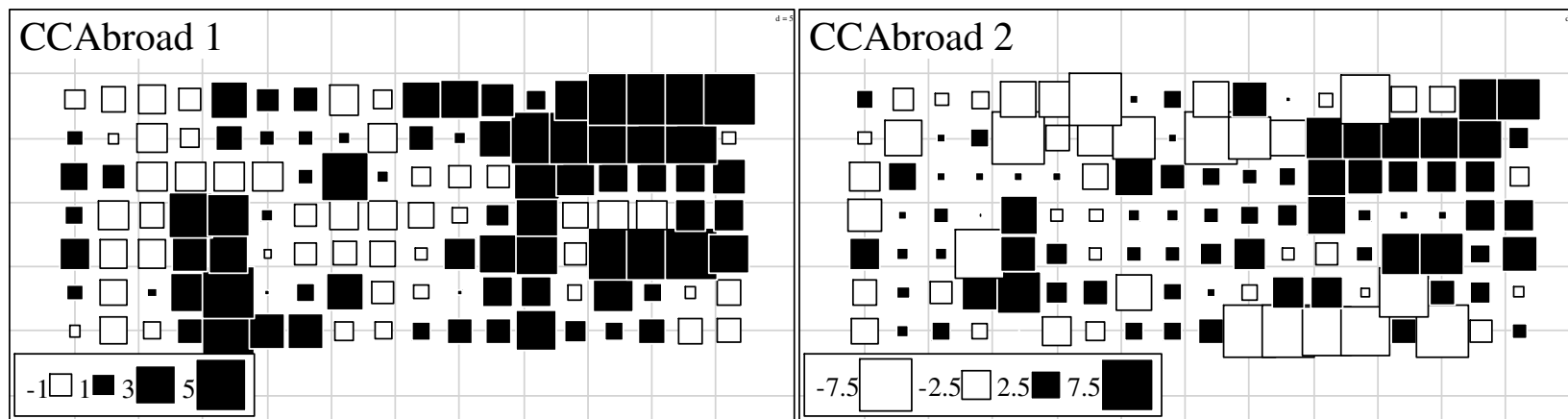

A

\section{CCAmed 1}

ロ $\mathbf{\square} \square \square \square \boldsymbol{\square} \square$

$\square \cdot \square \square \square(\square$

$\square$.

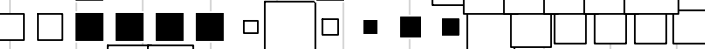

$\square \square \square$

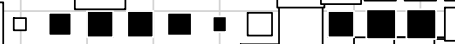

$\square \mathbf{\square}$

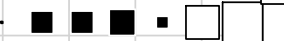

$\square \square \square$

$\square \square \square$ व

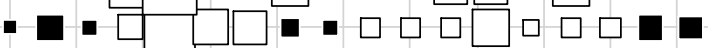

$-7 \square-5 \square-3 \square-1 \square \square_{1} \square$

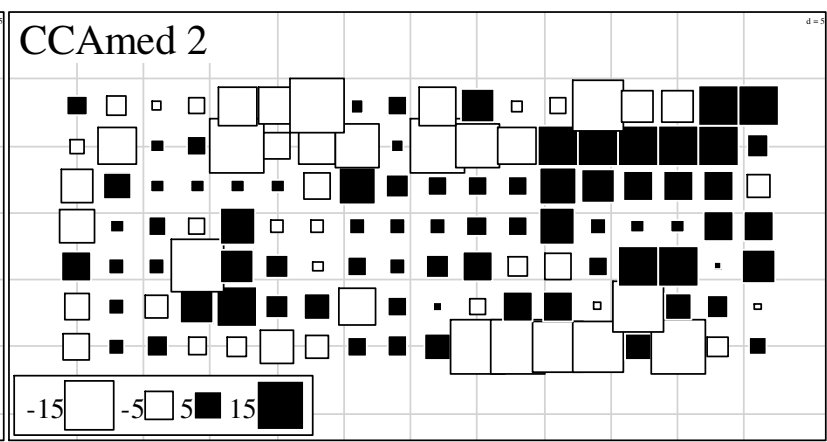

$\mathrm{B}$

CCAfine 1

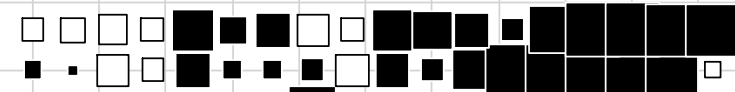

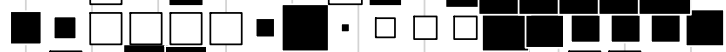

$\mathbf{\square} \square \square \cdot \square \square \square \square \square \mathbf{Q} \square \square \square \square \mathbf{\square}$

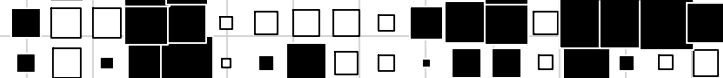

$\cdot \square \square \square \mid \square \square \square \cdot \square \square \square \square \cdot \square \square \square$

${ }_{2.2} \square 2.57 .5$

CCAfine 2

$\mathrm{C}$

Figure 7: Variation of broad-scale (A), medium-scale (B), and fine-scale (C) components of spatial variability in the mollusc community.

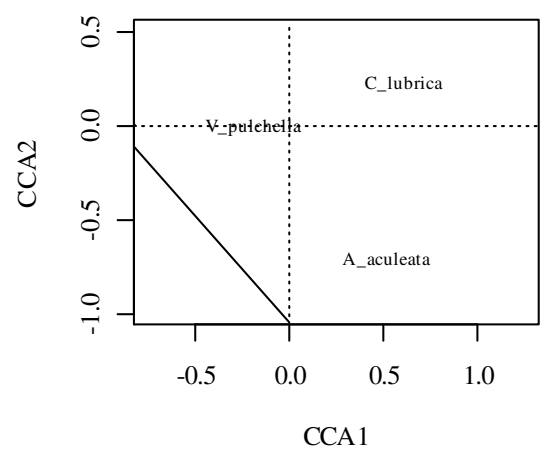

A

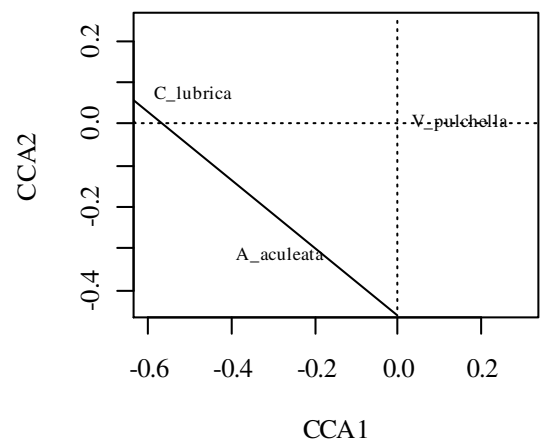

$\mathrm{B}$

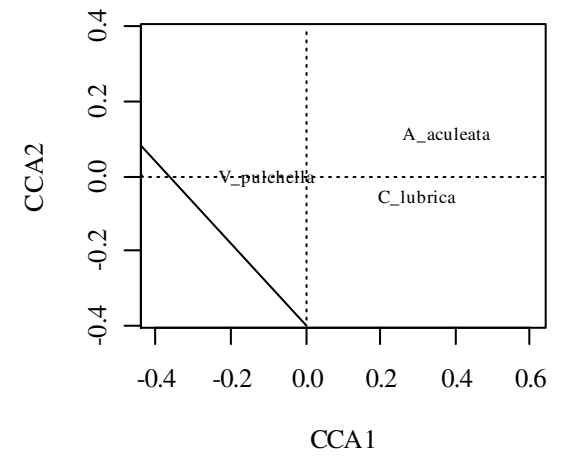

$\mathrm{C}$

Figure 8: Species correlation with the broad-scale (A), medium-scale (B), and fine-scale (C) components of spatial variability in the mollusc community. 


\section{Conclusion}

In the soils of the urban park, micromolluscs are represented by three species with a relatively high abundance. The micromolluscs are sensitive biological indicators of soil conditions and the direction of their transformation under the influence of recreation. The spatial variability of the micromollusc community has a hierarchical organization and is represented by the broad-scale, medium-scale, and fine-scale components. The key drivers of the broad-scale component are spatial location of trees and recreational load. The influence of recreation extends well beyond the geometric boundaries of recreational paths. The mediumscale component correlates with the spatial organization of soil aggregate structure and reflects the natural variability of soil properties. The fine-scale component of the spatial variation of the molluscan community is independent of the measured soil properties and is most likely the result of the structuring influence of inter-specific interactions.

\section{References}

Al-Shammary, A.A.G., Kouzani, A.Z., Kaynak, A., Khoo, S.Y., Norton, M., and Gates, W. (2018). Soil bulk density estimation methods: A review. Pedosphere, 28(4): 581-596. DOI: https://doi.org/10.1016/S1002-0160(18)60034-7.

Andrushenko, A.Y. and Zhukov, A.V. (2016). Scale-dependent effects in structure of the wintering ecological niche of the mute swan during wintering in the gulf of Sivash. Biological Bulletin of Bogdan Chmelnitskiy Melitopol State Pedagogical University, 6(3): 234-247. DOI: https://doi.org/10.15421/201691

Arriaga, F.J., Lowery, B. and Raper, R. (2011). Soil penetrometers and penetrability. In, Encyclopedia of Earth Sciences Series: Vol. Part 4 (pp. 757-760). Heidelberg: Springer Verlag GmbH. DOI: https://doi.org/10.1007/978-90-481-3585-1_207

Bécel, C., Vercambre, G. and Pagès, L. (2012). Soil penetration resistance, a suitable soil property to account for variations in root elongation and branching. Plant and Soil, 353(1-2): 169-180. DOI: https://doi.org/10.1007/s11104-011-1020-7

Bennie, A.T.P. and du Burger, R.T. (1988). Penetration resistance of fine sandy apedal soils as affected by relative bulk density, water content and texture. South African Journal of Plant and Soil, 5(1): 5-10. DOI: https://doi.org/10.1080/02571862.1988.10634239

Bennie, A.T.P. and Krynauw, G.N. (1985). Causes, adverse effects and control of soil compaction. South African Journal of Plant and Soil, 2(3): 109-114. DOI: https://doi.org/10.1080/02571862.1985.10634148

Bertrand, M., Barot, S., Blouin, M., Whalen, J., de Oliveira, T. and Roger-Estrade, J. (2015). Earthworm services for cropping systems. A review. Agronomy for Sustainable Development, 35(2): 553-567. DOI: https://doi.org/10.1007/s13593-014-0269-7

Blanchet, F.G., Legendre, P. and Borcard, D. (2008). Forward selection of explanatory variables. Ecology, 89(9): 2623-2632. DOI: https://doi.org/10.1890/07-0986.1

Borcard, D. and Legendre, P. (2002). All-scale spatial analysis of ecological data by means of principal coordinates of neighbour matrices. Ecological Modelling, 153(1-2): 51-68. DOI: https://doi.org/10.1016/S0304-3800(01)00501-4

Bray, N., Kao-Kniffin, J., Frey, S.D., Fahey, T. and Wickings, K. (2019). Soil macroinvertebrate presence alters microbial community composition and activity in the rhizosphere. Frontiers in Microbiology, 10(FEB): DOI: https://doi.org/10.3389/fmicb.2019.00256

Bronick, C.J. and Lal, R. (2005). Soil structure and management: A review. Geoderma, 124(1-2): 3-22. DOI: https://doi.org/10.1016/j.geoderma.2004.03.005

Byrne, L.B., Bruns, M.A. and Kim, K. C. (2008). Ecosystem properties of urban land covers at the aboveground-belowground interface. Ecosystems, 11(7): 1065-1077. DOI: https://doi.org/10.1007/s10021-008-9179-3

Byrne, L. and Bruns, M. (2004). The Effects of Lawn Management on Soil Microarthropods. Journal of Agricultural and Urban Entomology, 21: 151-156. DOI: https://docs.rwu.edu/fcas_fp/73 
Čejka, T. and Hamerlík, L. (2009). Land snails as indicators of soil humidity in Danubian woodland (SW Slovakia). Polish Journal of Ecology, 57(4): 741-747

Chang, L.W., Zelený, D., Li, C.F., Chiu, S.T. and Hsieh, C. F. (2013). Better environmental data may reverse conclusions about niche- and dispersal-based processes in community assembly. Ecology, 94(10): 2145-2151. DOI: https://doi.org/10.1890/12-2053.1

Chaplot, V. and Cooper, M. (2015). Soil aggregate stability to predict organic carbon outputs from soils. Geoderma, 243-244: 205-213. DOI: https://doi.org/10.1016/j.geoderma.2014.12.013

Chrenková, K., Mataix-Solera, J., Dlapa, P. and Arcenegui, V. (2014). Long-term changes in soil aggregation comparing forest and agricultural land use in different Mediterranean soil types. Geoderma, 235-236(1): 290-299. DOI: https://doi.org/10.1016/j.geoderma.2014.07.025

Chudomelová, M., Zelený, D. and Li, C.F. (2017). Contrasting patterns of fine-scale herb layer species composition in temperate forests. Acta Oecologica, 80: 24-31. DOI: https://doi.org/10.1016/j.actao.2017.02.003

Collins, J., Kinzig, A., Grimm, N., Fagan, W.F., Hope, D., Wu, J. and Borer, E. T. (2000). A new urban ecology. American Scientist, 88(5): 416-425

Delgado-Baquerizo, M., Powell, J.R., Hamonts, K., Reith, F., Mele, P., Brown, M.V., Dennis, P.G., Ferrari, B. C., Fitzgerald, A., Young, A., Singh, B.K. and Bissett, A. (2017). Circular linkages between soil biodiversity, fertility and plant productivity are limited to topsoil at the continental scale. New Phytologist, 215(3): 1186-1196. DOI: https://doi.org/10.1111/nph.14634

Deng, J., Orner, E.P., Chau, J.F., Anderson, E.M., Kadilak, A.L., Rubinstein, R.L., Bouchillon, G.M., Goodwin, R.A., Gage, D.J. and Shor, L.M. (2015). Synergistic effects of soil microstructure and bacterial EPS on drying rate in emulated soil micromodels. Soil Biology and Biochemistry, 83: 116124. DOI: https://doi.org/10.1016/j.soilbio.2014.12.006

Douglas, D.D., Brown, D.R. and Pederson, N. (2013). Land snail diversity can reflect degrees of anthropogenic disturbance. Ecosphere, 4(2): part28. DOI: https://doi.org/10.1890/ES12-00361.1

Dray, S., Bauman, D., Blanchet, G., Borcard, D., Clappe, S., Guenard, G., Jombart, T., Larocque, G., Legendre, P., Madi, N. and Wagner, H.H. (2018). adespatial: Multivariate Multiscale Spatial Analysis. $\mathrm{R}$ package version 0.3-2. Available online at: https://CRAN.Rproject.org/package=adespatial. https://rdrr.io/rforge/adespatial/ [Accessed on 30 April 2021]

Duchicela, J., Sullivan, T.S., Bontti, E. and Bever, J. D. (2013). Soil aggregate stability increase is strongly related to fungal community succession along an abandoned agricultural field chronosequence in the Bolivian Altiplano. Journal of Applied Ecology, 50(5): 1266-1273. DOI: https://doi.org/10.1111/1365-2664.12130

Fedoniuk, R.H., Fedoniuk, T.P., Zimaroieva, A.A., Pazych, V.M. and Zubova, O.V. (2020). Impact of air born technogenic pollution on agricultural soils depending on prevailing winds in Polissya region (NW Ukraine). Ecological Questions, 31(1): 1. DOI: https://doi.org/10.12775/EQ.2020.007

Fonte, S.J., Kong, A.Y.Y., van Kessel, C., Hendrix, P.F. and Six, J. (2007). Influence of earthworm activity on aggregate-associated carbon and nitrogen dynamics differs with agroecosystem management. Soil Biology and Biochemistry, 39(5): 1014-1022. DOI: https://doi.org/10.1016/j.soilbio.2006.11.011

Gan, H. and Wickings, K. (2017). Soil ecological responses to pest management in golf turf vary with management intensity, pesticide identity, and application program. Agriculture, Ecosystems and Environment, 246: 66-77. DOI: https://doi.org/10.1016/j.agee.2017.05.014

Griffiths, E. (1965). Micro-organisms and soil structure. Biological Reviews, 40(1): 129-142. DOI: https://doi.org/10.1111/j.1469-185x.1965.tb00799.x

Hotopp, K. (2002). Land snails and soil calcium in central Appalachian mountain forests. Southeastern Naturalist, 1(1): 27-44. DOI: https://doi.org/10.1656/1528-7092(2002)001[0027:LSASCI]2.0.CO;2

Joimel, S., Cortet, J., Jolivet, C.C., Saby, N.P.A., Chenot, E.D., Branchu, P., Consalès, J.N., Lefort, C., Morel, J.L. and Schwartz, C. (2016). Physico-chemical characteristics of topsoil for contrasted forest, agricultural, urban and industrial land uses in France. Science of the Total Environment, 545-546: 40-47. DOI: https://doi.org/10.1016/j.scitotenv.2015.12.035

Joimel, S., Schwartz, C., Hedde, M., Kiyota, S., Krogh, P.H., Nahmani, J., Pérès, G., Vergnes, A. and Cortet, J. (2017). Urban and industrial land uses have a higher soil biological quality than expected from 
physicochemical quality. Science of the Total Environment, 584-585: 614-621. DOI: https://doi.org/10.1016/j.scitotenv.2017.01.086

Jones, C.G., Lawton, J.H. and Shachak, M. (1994). Organisms as Ecosystem Engineers. Oikos, 69(3): 373. DOI: https://doi.org/10.2307/3545850

Jones, C.G. and Shachak, M. (1990). Fertilization of the desert soil by rock-eating snails. Nature, 346(6287): 839-841. DOI: https://doi.org/10.1038/346839a0

Jones, E.L. and Leather, S.R. (2012). Invertebrates in urban areas: A review. European Journal of Entomology, 109(4): 463-478. DOI: https://doi.org/10.14411/eje.2012.060

Klimkina, I., Kharytonov, M. and Zhukov, O. (2018). Trend analysis of water-soluble salts vertical migration in technogenic edaphotops of reclaimed mine dumps in western donbass (Ukraine). Environmental Research, Engineering and Management, 74(2): 82-93. DOI: https://doi.org/10.5755/j01.erem.74.2.19940

Kramarenko, S.S., Kunakh, O.N., Zhukov, A.V. and Andrusevich, E.V. (2016). Analysis of the spatial distribution patterns of the land snail populations: a geostatistic method approach. Bulletin of the Russian Far East Malacological Society. 18: 5-40.

Kunah, O.M., Zelenko, Y.V., Fedushko, M.P., Babchenko, A.V., Sirovatko, V.O. and Zhukov, O.V. (2019). The temporal dynamics of readily available soil moisture for plants in the technosols of the Nikopol Manganese Ore Basin. Biosystems Diversity, 27(2): 156-162. DOI: https://doi.org/10.15421/011921

Kunakh, O.M., Yorkina, N.V., Zhukov, O.V., Turovtseva, N.M., Bredikhina, Y.L. and Logvina-Byk, T.A. (2020). Recreation and terrain effect on the spatial variation of the apparent soil electrical conductivity in an urban park. Biosystems Diversity, 28(1): 3-8. DOI: https://doi.org/10.15421/012001

Kunakh, O.N., Kramarenko, S.S., Zhukov, A.V., Kramarenko, A.S. and Yorkina, N.V. (2018). Fitting competing models and evaluation of model parameters of the abundance distribution of the land snail Vallonia pulchella (Pulmonata, Valloniidae). Regulatory Mechanisms in Biosystems, 9(2): 198-202. DOI: https://doi.org/10.15421/021829

Kuznetsov, V.A. and Ryzhova, I.M. (2019). The influence of recreation on changes in the vital conditions of soil invertebrates. IOP Conference Series: Earth and Environmental Science, 368: 012028. DOI: https://doi.org/10.1088/1755-1315/368/1/012028

Kuznetsov, V.A., Ryzhova, I.M. and Stoma, G.V. (2017). Changes in the properties of soils of Moscow forest parks under the impact of high recreation loads. Eurasian Soil Science, 50(10): 1225-1235. DOI: https://doi.org/10.1134/S1064229317100052

Lehmann, J. and Kleber, M. (2015). The contentious nature of soil organic matter. Nature, 528(7580): 6068. DOI: https://doi.org/10.1038/nature16069

Lüttge, U. and Buckeridge, M. (2020). Trees: structure and function and the challenges of urbanization. Trees 26: 751. DOI: https://doi.org/10.1007/s00468-020-01964-1

Maamar, B., Nouar, B., Soudani, L., Maatoug, M., Azzaoui, M., Kharytonov, M., Wiche, O. and Zhukov, O. (2018). Biodiversity and dynamics of plant groups of Chebket El Melhassa region (Algeria). Biosystems Diversity, 26(1): 62-70. DOI: https://doi.org/10.15421/011810

Maraun, M., Martens, H., Migge, S., Theenhaus, A. and Scheu, S. (2003). Adding to "the enigma of soil animal diversity": Fungal feeders and saprophagous soil invertebrates prefer similar food substrates. European Journal of Soil Biology, 39(2): 85-95. DOI: https://doi.org/10.1016/S11645563(03)00006-2

Martin, K. and Sommer, M. (2004a). Relationships between land snail assemblage patterns and soil properties in temperate-humid forest ecosystems. Journal of Biogeography, 31(4): 531-545. DOI: https://doi.org/10.1046/j.1365-2699.2003.01005.x

Martin, K. and Sommer, M. (2004b). Effects of soil properties and land management on the structure of grassland snail assemblages in SW Germany. Pedobiologia, 48(3): 193-203. DOI: https://doi.org/10.1016/j.pedobi.2003.12.004

Mcintyre, N.E., Knowles-Yánez, K. and Hope, D. (2000). Urban ecology as an interdisciplinary field: differences in the use of "urban" between the social and natural sciences. Urban Ecosystems, 4(1): 5-24. DOI: https://doi.org/10.1023/A:1009540018553 
Mexia, T., Vieira, J., Príncipe, A., Anjos, A., Silva, P., Lopes, N., Freitas, C., Santos-Reis, M., Correia, O., Branquinho, C. and Pinho, P. (2018). Ecosystem services: Urban parks under a magnifying glass. Environmental Research, 160: 469-478. DOI: https://doi.org/10.1016/j.envres.2017.10.023

Millar, A.J. and Waite, S. (1999). Mollusks in coppice woodland. Journal of Conchology, 36: 25-48.

Mummey, D.L., Rillig, M.C. and Six, J. (2006). Endogeic earthworms differentially influence bacterial communities associated with different soil aggregate size fractions. Soil Biology and Biochemistry, 38(7): 1608-1614. DOI: https://doi.org/10.1016/j.soilbio.2005.11.014

Mustafa, A., Minggang, X., Ali Shah, S.A., Abrar, M.M., Nan, S., Baoren, W., Zejiang, C., Saeed, Q., Naveed, M., Mehmood, K. and Núñez-Delgado, A. (2020). Soil aggregation and soil aggregate stability regulate organic carbon and nitrogen storage in a red soil of southern China. Journal of Environmental Management, 270: 110894. DOI: https://doi.org/10.1016/j.jenvman.2020.110894

Nahmani, J. and Lavelle, P. (2002). Effects of heavy metal pollution on soil macrofauna in a grassland of Northern France. European Journal of Soil Biology, 38(3-4): 297-300. DOI: https://doi.org/10.1016/S1164-5563(02)01169-X

Oades, J. and Waters, A. (1991). Aggregate hierarchy in soils. Australian Journal of Soil Research, 29(6): 815-828. DOI: https://doi.org/10.1071/SR9910815

Oksanen, J., Blanchet, F.G., Friendly, M., Kindt, R., Legendre, P., McGlinn, D., Minchin, P.R., O’Hara, R.B., Simpson, G.L., Solymos, P., Stevens, M.H.H., Szoecs, E. and Wagner, H. (2019). vegan: Community Ecology Package. R package version 2.5-6. Available online at: https://CRAN.Rproject.org/package=vegan. https://cran.r-project.org/package=vegan [Accessed on 30 April 2021]

Pakhomov, O.Y., Kunakh, O.M., Babchenko, A.V., Fedushko, M.P., Demchuk, N.I., Bezuhla, L.S. and Tkachenko, O.S. (2019). Temperature effect on the temporal dynamic of terrestrial invertebrates in technosols formed after reclamation at a post-mining site in Ukrainian steppe drylands. Biosystems Diversity, 27(4): 322-328. DOI: https://doi.org/10.15421/011942

Pavao-Zuckerman, M.A. (2008). The nature of urban soils and their role in ecological restoration in cities. Restoration Ecology, 16(4): 642-649. DOI: https://doi.org/10.1111/j.1526-100X.2008.00486.x

Pavao-Zuckerman, M.A. and Coleman, D.C. (2007). Urbanization alters the functional composition, but not taxonomic diversity, of the soil nematode community. Applied Soil Ecology, 35(2): 329-339. DOI: https://doi.org/10.1016/j.apsoil.2006.07.008

Peck, D.C. (2009). Comparative impacts of white grub (Coleoptera: Scarabaeidae) control products on the abundance of non-target soil-active arthropods in turfgrass. Pedobiologia, 52(5): 287-299. DOI: https://doi.org/10.1016/j.pedobi.2008.10.003

Pey, B., Nahmani, J., Auclerc, A., Capowiez, Y., Cluzeau, D., Cortet, J.Ô., Decaëns, T., Deharveng, L., Dubs, F., Joimel, S., Briard, C., Grumiaux, F., Laporte, M.A., Pasquet, A., Pelosi, C., Pernin, C., Ponge, J. F., Salmon, S., Santorufo, L. and Hedde, M. (2014). Current use of and future needs for soil invertebrate functional traits in community ecology. Basic and Applied Ecology, 15(3): 194-206. DOI: https://doi.org/10.1016/j.baae.2014.03.007

Pinkina, T., Zymaroieva, A., Matkovska, S., Svitelskyi, M., Ishchuk, O. and Fediuchka, M. (2019). Trophic characteristics of Lymnaea stagnalis (Mollusca: Gastropoda: Lymnaeidae) in toxic environment. Ekológia (Bratislava), 38(3): 292-300. DOI: https://doi.org/10.2478/eko-2019-0022

Ponge, J.F. (1991). Food resources and diets of soil animals in a small area of Scots pine litter. Geoderma, 49(1-2): 33-62. DOI: https://doi.org/10.1016/0016-7061(91)90090-G

Pouyat, R.V., Yesilonis, I.D., Dombos, M., Szlavecz, K., Setälä, H., Cilliers, S., Hornung, E., Kotze, D.J. and Yarwood, S. (2015). A global comparison of surface soil characteristics across five cities: A test of the urban ecosystem convergence hypothesis. Soil Science, 180(4-5): 136-145. DOI: https://doi.org/10.1097/SS.0000000000000125

Quiroga, A.R., Buschiazzo, D.E. and Peinemann, N. (1999). Soil compaction is related to management practices in the semi-arid Argentine pampas. Soil and Tillage Research, 52(1-2): 21-28. DOI: https://doi.org/10.1016/S0167-1987(99)00049-5

Rao, C. (1964). The use and interpretation of principal component analysis in applied research. Sankhya A, 26: 329-358.

Rillig, M.C., Muller, L.A.H. and Lehmann, A. (2017). Soil aggregates as massively concurrent evolutionary 
incubators. ISME Journal, 11(9): 1943-1948. DOI: https://doi.org/10.1038/ismej.2017.56

Rillig, M.C. and Mummey, D.L. (2006). Mycorrhizas and soil structure. New Phytologist, 171(1): 41-53. DOI: https://doi.org/10.1111/j.1469-8137.2006.01750.x

Rivera, J.I. and Bonilla, C.A. (2020). Predicting soil aggregate stability using readily available soil properties and machine learning techniques. Catena, 187: 104408. DOI: https://doi.org/10.1016/j.catena.2019.104408

Rochefort, S., Therrien, F., Shetlar, D.J. and Brodeur, J. (2006). Species diversity and seasonal abundance of Collembola in turfgrass ecosystems of North America. Pedobiologia, 50(1): 61-68. DOI: https://doi.org/10.1016/j.pedobi.2005.10.007

Salminen, J., van Gestel, C.A.M. and Oksanen, J. (2001). Pollution-induced community tolerance and functional redundancy in a decomposer food web in metal-stressed soil. Environmental Toxicology and Chemistry, 20(10): 2287-2295. DOI: https://doi.org/10.1002/etc.5620201022

Santorufo, L., van Gestel, C.A.M., Rocco, A. and Maisto, G. (2012). Soil invertebrates as bioindicators of urban soil quality. Environmental Pollution, 161: 57-63. DOI: https://doi.org/10.1016/j.envpol.2011.09.042

Schilthuizen, M., Chai, H.N., Kimsin, T.E. and Vermeulen, J.J.C. (2003). Abundance and diversity of landsnails (Mollusca: Gastropoda) on limestone hills in Borneo. The Raffles Bulletin of Zoology, 51(1): $35-42$.

Schrader, S. and Böning, M. (2006). Soil formation on green roofs and its contribution to urban biodiversity with emphasis on Collembolans. Pedobiologia, 50(4): 347-356. DOI: https://doi.org/10.1016/j.pedobi.2006.06.003

Scoggins, H.L. and van Iersel, M.W. (2006). In situ probes for measurement of electrical conductivity of soilless substrates: Effects of temperature and substrate moisture content. HortScience , 41(1): 210 214. DOI: https://doi.org/10.21273/hortsci.41.1.210

Silvan, N., Laiho, R. and Vasander, H. (2000). Changes in mesofauna abundance in peat soils drained for forestry. Forest Ecology and Management, 133(1-2): 127-133. DOI: https://doi.org/10.1016/S03781127(99)00303-5

Smetak, K.M., Johnson-Maynard, J.L. and Lloyd, J.E. (2007). Earthworm population density and diversity in different-aged urban systems. Applied Soil Ecology, 37(1-2): 161-168. DOI: https://doi.org/10.1016/j.apsoil.2007.06.004

Sodhi, G.P.S., Beri, V. and Benbi, D.K. (2009). Soil aggregation and distribution of carbon and nitrogen in different fractions under long-term application of compost in rice-wheat system. Soil and Tillage Research, 103(2): 412-418. DOI: https://doi.org/10.1016/j.still.2008.12.005

Teluk, P., Yorkina, N.V., Umerova, A., Budakova, V.S., Nydion, N.M. and Zhukov, O.V. (2020). Estimation of the level of recreational transformation of public green spaces by indicators of soil penetration resistance. Agrology, 3(3): 171-180. DOI: https://doi.org/10.32819/020020

Thompson, L., Thomas, C.D., Radley, J.M.A., Williamson, S. and Lawton, J.H. (1993). The effect of earthworms and snails in a simple plant community. Oecologia, 95(2): 171-178. DOI: https://doi.org/10.1007/BF00323487

Thuiller, W., Lavorel, S., Midgley, G., Lavergne, S. and Rebelo, T. (2004). Relating plant traits and species distributions along bioclimatic gradients for 88 Leucadendron taxa. Ecology, 85(6): 1688-1699. DOI: https://doi.org/10.1890/03-0148

Tisdall, J.M. and Oades, J.M. (1982). Organic matter and water-stable aggregates in soils. Journal of Soil Science, 33(2): 141-163. DOI: https://doi.org/10.1111/j.1365-2389.1982.tb01755.x

Wagg, C., Bender, S.F., Widmer, F. and van der Heijden, M.G.A. (2014). Soil biodiversity and soil community composition determine ecosystem multifunctionality. Proceedings of the National Academy of Sciences of the United States of America, 111(14): 5266-5270. DOI: https://doi.org/10.1073/pnas.1320054111

Wang, W., Wu, T., Li, Y., Xie, S., Han, B., Zheng, H. and Ouyang, Z. (2020). Urbanization Impacts on Natural Habitat and Ecosystem Services in the Guangdong-Hong Kong-Macao "Megacity." Sustainability, 12(16): 6675. DOI: https://doi.org/10.3390/su12166675

Wick, A.F., Daniels, W.L., Nash, W.L. and Burger, J.A. (2016). Aggregate Recovery in Reclaimed Coal 
Mine Soils of SW Virginia. Land Degradation \& Development, 27(4): 965-972. DOI: https://doi.org/10.1002/ldr.2309

Wick, A.F., Stahl, P.D. and Ingram, L.J. (2009). Aggregate-Associated Carbon and Nitrogen in Reclaimed Sandy Loam Soils. Soil Science Society of America Journal, 73(6): 1852-1860. DOI: https://doi.org/10.2136/sssaj2008.0011

Wilpiszeski, R.L., Aufrecht, J.A., Retterer, S.T., Sullivan, M.B., Graham, D.E., Pierce, E.M., Zablocki, O.D., Palumbo, A.V. and Elias, D.A. (2019). Soil Aggregate Microbial Communities: Towards Understanding Microbiome Interactions at Biologically Relevant Scales. Applied and Environmental Microbiology, 85(14): e00324-19. DOI: https://doi.org/10.1128/AEM.00324-19

Xu, Z., Hou, Y., Zhang, L., Liu, T. and Zhou, G. (2016). Ecosystem responses to warming and watering in typical and desert steppes. Scientific Reports, 6(1): 34801. DOI: https://doi.org/10.1038/srep34801

Yorkina, N., Maslikova, K., Kunah, O. and Zhukov, O. (2018). Analysis of the spatial organization of Vallonia pulchella (Muller, 1774) ecological niche in Technosols (Nikopol manganese ore basin, Ukraine). Ecologica Montenegrina, 17(1): 29-45.

Yorkina, N., Zhukov, O. and Chromysheva, O. (2019). Potential possibilities of soil mesofauna usage for biodiagnostics of soil contamination by heavy metals. Ekologia Bratislava, 38(1): 1-10. DOI: https://doi.org/10.2478/eko-2019-0001

Yorkina, N.V. (2016). Impact of technogenic pollution of urban environment on vitality indicators of urban biota (Mollusk fauna, soil mesofauna, epiphytic lichens). Moscow University Biological Sciences Bulletin, 71(3): 177-183. DOI: https://doi.org/10.3103/S0096392516030044

Yorkina, N.V., Kunakh, O.M. and Budakova, V.S. (2019). Ecological niche packing and spatial organisation of the urban park macrofauna comminity. Agrology, 2(4): 209-218. DOI: https://doi.org/doi: $10.32819 / 019030$

Yorkina, N.V., Podorozhniy, S.M., Velcheva, L.G., Honcharenko, Y.V. and Zhukov, O.V. (2020). Applying plant disturbance indicators to reveal the hemeroby of soil macrofauna species. Biosystems Diversity, 28(2): 181-194. DOI: https://doi.org/10.15421/012024

Young, G.D., Adams, B.A. and Topp, G.C. (2000). A portable data collection system for simultaneous cone penetrometer force and volumetric soil water content measurements. Canadian Journal of Soil Science, 80(1): 23-31. DOI: https://doi.org/10.4141/S99-025

Zhang, M., Cai, Q., Xu, Y., Kong, L., Tan, L. and Wang, L. (2012). Spatial Distribution of Macroinvertebrate Community along a Longitudinal Gradient in a Eutrophic Reservoir-Bay during Different Impoundment Stages, China. International Review of Hydrobiology, 97(3): 169-183. DOI: https://doi.org/10.1002/iroh.201111488

Zhukov, A.V. (2015a). Phytoindicator estimation of the multidimensional scaling of the plant community structure. Biological Bulletin of Bogdan Chmelnitskiy Melitopol State Pedagogical University, 1(1): 69-93. DOI: https://doi.org/10.15421/2015005

Zhukov, A.V. (2015b). Influence of usual and dual wheels on soil penetration resistance: the GIS-approach. Biological Bulletin of Bogdan Chmelnitskiy Melitopol State Pedagogical University, 5(3): 73-100. DOI: https://doi.org/10.15421/2015029

Zhukov, A.V., Kunah, O.N., Novikova, V.A. and Ganzha, D.S. (2016a). Phytoindicacion estimation of soil mesopedobionts communities catena and their ecomorphic organization. Biological Bulletin of Bogdan Chmelnitskiy Melitopol State Pedagogical University, 6(3): 91-117. DOI: https://doi.org/10.15421/201676

Zhukov, A.V. and Zadorozhnaya, G.A. (2016). Spatio-temporal dynamics of the penetration resistance of recultivated soils formed after open cast mining. Visnyk of Dnipropetrovsk University. Biology, Ecology, 24(2): 324-331. DOI: https://doi.org/10.15421/011642

Zhukov, O.V., Kunah, O.N. and Novikova, V.A. (2016). The functional organisation of the mesopedobionts community of sod pinewood soils on arena of the river Dnepr. Visnyk of Dnipropetrovsk University. Biology, Ecology, 24(1): 26-39. DOI: https://doi.org/10.15421/011604

Zhukov, O.V., Kunakh, O.M., Taran, V.O. and Lebedinska, M.M. (2016b). Spatial variability of soils electrical conductivity within arena of the river dnepr valley (territory of the natural reserve "Dniprovsko-Orilsky"). Biological Bulletin of Bogdan Chmelnitskiy Melitopol State Pedagogical 
University, 6(2): 129-157. DOI: https://doi.org/10.15421/201646

Zhukov, O.V., Pisarenko, P.V., Kunah, O.M. and Dichenko, O.J. (2015). Role of landscape diversity in dynamics of abundance of sugar beet pests population in Poltava region. Visnyk of Dnipropetrovsk University. Biology, Ecology, 23(1): 21-27. DOI: https://doi.org/10.15421/011504 


\section{Authors' Declarations and Essential Ethical Compliances}

Authors' Contributions (in accordance with ICMJE criteria for authorship)
\begin{tabular}{|l|l|l|l|l|l|}
\hline Contribution & Author 1 & Author 2 & Author 3 & Author 4 & Author 5 \\
\hline $\begin{array}{l}\text { Conceived and designed the research } \\
\text { or analysis }\end{array}$ & Yes & Yes & Yes & Yes & Yes \\
\hline Collected the data & Yes & Yes & Yes & Yes & Yes \\
\hline $\begin{array}{l}\text { Contributed to data analysis \& } \\
\text { interpretation }\end{array}$ & Yes & Yes & Yes & Yes & Yes \\
\hline Wrote the article/paper & Yes & Yes & Yes & Yes & Yes \\
\hline Critical revision of the article/paper & Yes & Yes & No & No & Yes \\
\hline Editing of the article/paper & Yes & No & No & No & No \\
\hline Supervision & Yes & No & No & No & No \\
\hline Project Administration & Yes & No & No & No & No \\
\hline Funding Acquisition & Yes & No & No & No & No \\
\hline Overall Contribution Proportion $(\%)$ & 30 & 20 & 20 & 20 & 10 \\
\hline
\end{tabular}

\section{Funding}

No funding was available for the research conducted for and writing of this paper.

Research involving human bodies (Helsinki Declaration)

Has this research used human subjects for experimentation? No

Research involving animals (ARRIVE Checklist)

Has this research involved animal subjects for experimentation? No

\section{Research involving Plants}

During the research, the authors followed the principles of the Convention on Biological Diversity and the Convention on the Trade in Endangered Species of Wild Fauna and Flora.

Research on Indigenous Peoples and/or Traditional Knowledge

Has this research involved Indigenous Peoples as participants or respondents? No

(Optional) PRISMA (Preferred Reporting Items for Systematic Reviews and Meta-Analyses)

Have authors complied with PRISMA standards? Yes

\section{Competing Interests/Conflict of Interest}

Authors have no competing financial, professional, or personal interests from other parties or in publishing this manuscript.

\section{Rights and Permissions}

Open Access. This article is licensed under a Creative Commons Attribution 4.0 International License, which permits use, sharing, adaptation, distribution and reproduction in any medium or format, as long as you give appropriate credit to the original author(s) and the source, provide a link to the Creative Commons license, and indicate if changes were made. The images or other third-party material in this article are included in the article's Creative Commons license, unless indicated otherwise in a credit line to the material. If material is not included in the article's Creative Commons license and your intended use is not permitted by statutory regulation or exceeds the permitted use, you will need to obtain permission directly from the copyright holder. To view a copy of this license, visit http://creativecommons.org/licenses/by/4.0/. 